\title{
Academic Supervision in Improving Teacher Professionalism
}

\author{
Elliana ${ }^{2}$, Yusrizal 2, Nasir Usman 3 \\ DOI: $10.35445 /$ alishlah.v13i1. 527
}

\begin{abstract}
Info Artikel
Abstract

Keywords: supervision academic headmaster teacher professionalism

This study aims to obtain empirical data about academic supervision in improving teacher professionalism at Lhokseumawe State Vocational High School. Academic supervision must be based on data, objective facts. Academic supervision is routine work that supervisors must carry out because of a dynamic curriculum that requires improvement in both documentation and contextually in the field. The method in this research uses a qualitative approach with descriptive analysis methods. The primary data sources of this study were obtained from direct interviews with informants consisting of school principals, teachers, and students, results from observations, and secondary sources obtained from various studies of documents, texts, and archives related to the implementation of Academic Supervision. The principal has carried out academic supervision in improving teacher professionalism, evidenced by the planning of supervision schedules, implementing, assessing the results of teacher performance using learning instruments prepared, and following up on the results of learning supervision. Supervision theory has been implemented well, one of which is directive supervision in learning and implementing initial meetings with teacher interviews carried out before implementing supervision.
\end{abstract}

Kata kunci: pengawasan akademik kepala sekolah guru profesionalisme

\begin{abstract}
Abstrak
Penelitian ini bertujuan untuk mendapatkan data empiris tentang supervisi akademik dalam meningkatkan professional guru di SMK Negeri Lhokseumawe. Supervisi akademik harus berdasarkan data, fakta yang obyektif. Supervisi akademik adalah satu kerja rutinitas yang harus dilakukan oleh supervisor karena tuntutan kurikulum yang dinamis yang terus membutuhkan penyempurnaan baik secara dokumentasi maupun secara kontekstual dilapangan. Metodologi dalam penelitian menggunakan pendekatan kualitatif dengan metode analisis deskriptif. Sumber data primer penelitian ini didapatkan dari hasil wawancara langsung dengan informan yang terdiri dari kepala sekolah, guru dan peserta didik, serta hasil dari observasi, serta sumber skunder diperoleh dari berbagai studi dokumen, naskah, dan arsip yang berkaitan dengan pelaksanaan Supervisi Akademik. Berdasarkan hasil analisa peneliti bahwa Kepala Sekolah telah melaksanakan supervisi akademik dalam meningkatkan profesionalisme guru ini dibuktikan dengan pembuatan perencanaan jadwal supervisi, melaksanakan, menilai hasil kinerja guru dengan memakai instrumen pembelajaran yang telah dipersiapkan
\end{abstract}

\footnotetext{
${ }^{1}$ Universitas Syiah Kuala, Banda Aceh, Indonesia SMK Negeri 1 Lhokseumawe.

Email: elliana281074@gmail.com

${ }^{2}$ Universitas Syiah Kuala, Banda Aceh, Indonesia

Email: yusrizal_fkip@unsyiah.ac.id

3 Universitas Syiah Kuala, Banda Aceh, Indonesia

Email: nasir.fkip@gmail.com
} 
dan menindaklanjuti dari hasil supervisi pembelajaran.Pelaksanaan supervisi akademik ditinjau dari segi teori-teori supervisi telah dilaksanakan dengan baik yaitu salah satu diantaranya adalah pendekatan supervisi direktif dalam pembelajaran dan dilaksanakannya temu awal wawancara dengan guru yang dilaksanakan sebelum pelaksanaan supervise.

\section{INTRODUCTION}

Every human being must have access to education in order to continue to improve. Essentially, education entails transferring knowledge from teachers to students and developing an upbeat personality in students. As a result, education aims to produce students with superior knowledge, attitudes, and abilities. Wahyuni (2015: 2), on the other hand, says that education in Indonesia is different.

Article 3 of Law No. 20 of 2003 states: "National education aims to develop students' potential to become human beings who believe in and are devoted to God Almighty, possess noble character, knowledge, competence, creativity, and independence, as well as to become democratic and responsible citizens." As a result, the educational function must be considered to accomplish the objectives of national education.

Schools, as educational institutions, play a critical role in shaping the nation's destiny. If the production process is represented, input is received, processed, and finally output. In education, the input is the students accepted into the school level, and the output is the students' graduates. In this situation, the school serves as a clearinghouse for these students' processing in order to create the expected output of school graduates. Additionally, because the teacher is the primary actor in education and the person who determines the success or failure of the learning process, a teacher must have sufficient capacity to develop his or her creativity to improve his or her performance.

The quality of education is a set of high-quality standards that must be reached in order for education to be considered acceptable. In education, quality encompasses inputs, processes, outputs, and outcomes. When ready for processing, the quality process produces an environment conducive to active, creative, and pleasant learning. Quality output occurs when students achieve excellent academic and non-academic learning outcomes, and quality output occurs when it is quickly incorporated into the world of work.

The educator cannot compartmentalize education within an academic unit. The educator is a teacher who educates both within and outside of the organization. As a result, instructors in school organizations should accomplish their responsibilities or demonstrate superior performance and possess teaching competencies. Teacher competency is a set of abilities, knowledge, and attitudes that teachers must possess, manage, and guide to fulfill their job responsibilities. Competence is the enshrinement of information or reasoning ability, attitudes, and abilities manifested in actions (Sagala, 2013: 23). Additionally, teacher performance can be measured by the extent to which required competencies are met. These competencies include pedagogical ability, personal ability, social ability, and professional ability. A teacher must maintain motivation and the ability to increase their skills at all times.

Numerous studies on academic supervision have been conducted previously. One of them assists teachers in increasing their capacity to accomplish learning objectives in the classroom (Kemat, 2016). Academic monitoring also assists teachers in becoming professional educators for their students (Astuti, 2016). Academic supervision can help increase teacher motivation (Rosilawati, 2014). Academic supervision activities will invigorate the learning process (Harahap, 2014). According to Astuti (2017), this activity can help develop teacher performance, particularly experienced in developing administrative evaluation structures. It has a positive and significant effect on principal supervision and teacher performance in the classroom (Amanda et al., 2017). Teachers might enhance their effectiveness by supervising academic/instructional activities (Zakso \& Radiana, 2013). In other words, the academic supervision function does not simply evaluate a 
teacher's effectiveness in managing a classroom; instead, such activities help teachers develop into professional educators (Bahri, 2014; Rasmita, 2019).

This research is distinct from earlier research. The purpose of this study is to determine the effect of academic supervision on teacher professionalism. This study is judged required to be conducted as a reference for developing educational services that adhere to established criteria and for improving the quality of education, particularly in the institution where the research is conducted.

\section{METHOD}

This study takes a qualitative approach. As a result, this research is classified as descriptive because the data evaluated are based on respondents' views and opinions. Perceptions of Academic Supervision of Supervisors in Improving Teacher Pedagogic Competence at SMK Negeri 1 Lhokseumawe are elicited. It is frequently referred to as the lens theory or perspective theory in qualitative research. According to Creswell (2017:44), a theoretical lens or perspective in qualitative research: "provides an overarching orienting lens through which the topic of gender, class, and race can be studied" (or other issues of a marginalized group). This lens develops into an advocacy perspective that affects the types of questions addressed, guides the collection and analysis of data, and serves as a rallying cry for action or change. One may argue that the lens or perspective theory is the theory employed in qualitative research. Theory serves to assist researchers in developing a variety of research topics, directing how to collect and analyze data.

The data gathering approach used in this study was observation and documenting. The researcher directly observes items necessary for this study, such as social settings involving places, people, objects, or continuous activities. Researchers observe activities to enhance teachers' abilities as a reference point.

SMK Negeri 1 Lhokseumawe and SMK Negeri 3 Lhokseumawe were used for the research. These two schools are the city of Lhokseumawe's most sought-after vocational secondary education institutions.

\section{FINDINGS AND DISCUSSION}

\section{The Implementation of Academic Supervision for the Teacher}

The principals of SMKN 1 and SMKN 3 Lhokseumawe indicated that in order to develop teacher professionalism, schools provide academic supervision activities led by supervisors and principals both individually and in groups. Additionally, the principal of SMKN 3 Lhokseumawe said that both supervisors and principals conduct routine supervision activities in schools. This supervision activity is conducted in order to enhance not only teacher professionalism but also teacher pedagogical competency.

Academic supervision actions are systematic and sustained. This activity is repeated once a semester. Academic supervision programs are developed at the start of each academic year, and academic supervision activities are implemented after six weeks of the learning process. The principal, supervisor, and vice-principal are all involved in establishing the supervision plan. The supervisor oversees several areas of learning, including learning planning (management of learning materials such as syllabuses, lesson plans, and journals), the learning process (methods, techniques, and aspects of learning), and learning evaluation. This finding is consistent with Suryani's (2015) research finding that the educational supervision program is prepared and implemented at the start of the odd semester or school year. In contrast, the educational supervision program is evaluated at the end of each odd and even semester to determine the extent to which the program has been executed. Messi (2018) also discovered that the supervisor supervises learning planning features such as the annual program, semester program, syllabus, lesson plan (RPP), daily agenda, list of grades, maximum completeness criteria (KKM), educational calendar, face-to-face schedule, and attendance students. The follow-up components of supervisory activities are focused on improving the quality of learning outcomes, aspects of KBM implementation, class management, beginning 
with the opening activities, core activities, and assessment of learning. These are the most important aspects of supervision.

Academic supervision activities are not limited to enhancing teachers' professionalism; they also aim to enhance the quality and quantity of teachers as educators. This is done to ensure that the classroom's teaching and learning processes support the school's vision and mission. This supervision activity occurs at the beginning of the semester to allow for adjustments to be made as the teaching and learning process progresses if necessary. Supervision activities must be conducted in order to develop teacher professionalism, as supervision can see how a teacher performs his or her obligations. This finding is consistent with Rachmawati's (2016) assertion that it is critical to improving the quality of education because a high-quality education produces high-quality graduates. Thus, as the spearheads of schools' teaching and learning processes, teachers must always pay attention to how they teach and maintain their professionalism as educators.

\section{The Implementation of Academic Supervision in Improving Teacher Professionalism}

As stated by the teacher at SMKN 1 Lhokseumawe, supervisory activities are critical for enhancing teachers' professionalism as educators. It aims to evaluate teacher performance and build confidence and responsibility for assigned responsibilities. In response, the school supervisor explained that while this supervision activity is expected to improve teachers' professionalism in carrying out their duties, teachers have thus far demonstrated an increase in their performance and professionalism in carrying out this task, which is a very positive development the field of education.

The principle of SMKN 1 Lhokseumawe noted that so far, all supervisory activities have been conducted under the guidelines. Additionally, the head of SMKN 3 Lhokseumawe indicated that the monitoring was carried out according to plan, with prior notification and access to all records. Additionally, the school supervisor stated that the academic supervision activities are planned and implemented by the school education quality assurance team (TPMPS).

The principal of SMK Negeri 3 Lhokseumawe noted that coaching teachers through a fun school method, beginning with empathy for teachers and inquiring about challenges and barriers to learning, help him pursue his goal of meeting learning standards. It will develop instructors' professional competence through constant supervision via a "fun school" approach.

The schedule for carrying out supervision tasks is agreed upon, and the selection of the supervised instructor is done randomly and takes into account the individual's desire. Each teacher who has conducted supervision meets with the supervisor to provide results and improvement efforts to enhance teachers' professionalism as educators.

Numerous benefits can be derived from academic supervision activities in accomplishing educational goals. The instructor and the completeness of teaching and learning in the classroom are the targets of academic monitoring. As previously stated, SMK Negeri 3 Lhokseumawe noted that academic supervision activities are a critical component of the educational growth cycle. As such, the implementation method must be enhanced year after year. This supervision is a self-evaluation from the teacher's perspective; whatever recommendations are made, they will undoubtedly strengthen both pedagogic and professional competencies. It is consistent with Ilham's (2017) assertion that supervision is a service provided to instructors to enhance teaching, learning, and curriculum. Supervision is a service to instructors aimed at improving performance. To accomplish these goals, teachers must always seek fresh breakthroughs in leading pupils in a way that motivates them (Warisno, 2018).

\section{Academic supervision as a means of enhancing teacher professionalism}

To achieve a high standard of education, it is necessary to have professional and effective teachers. To enhance teacher professionalism, supervisory activities are conducted to evaluate teacher performance and to help educators develop their professionalism. As stated by the Lhokseumawe State Vocational School supervisor, following supervision, a special meeting with the newly supervised teacher should be held to communicate findings and give follow-up to improve teacher professional quality and performance. 
Follow-up is a continuous activity that allows for the continuation of what has been learned due to these supervision activities as discoveries, either through assignment or participation in training. Following supervision, there is always a follow-up in administrative changes if something is erroneous; if it fits the standards, the principal appoints the individual as a peer tutor in the school setting. The supervisor will be able to determine the teacher's capacity to carry out his tasks, his professionalism in carrying out his obligations, and recommendations for future changes based on the outcomes of the supervision activity. Instructors who play a critical role are expected to perform in line with their primary tasks and obligations, requiring schools to continue developing professional teachers to foster a positive teaching and learning environment. According to Prasojo (2015), monitoring is necessary for education to develop their professional performance further. The supervisor's role is to observe, monitor, and oversee the monitored individual's progress in carrying out their primary responsibilities, including improving or enhancing the student learning process to obtain maximum learning results.

\section{Obstacles to academic supervision implementation}

According to the principal of SMK Negeri 3 Lhokseumawe, a frequent source of conflict in academic supervision is the changing form of the vocational high school curriculum. This forces teachers to rethink their resources, methods, approaches, strategies, and approaches to learning from the start. Another impediment is a spontaneous activity from the office, school, and subjects themselves. Nonetheless, the principal asserts that a small number of teachers are less able to collaborate when supervised, rendering the process of performing supervision activities suboptimal. The majority of teachers indicated that they could be supervised but were still not performing optimally due to the numerous jobs and activities performed by the teacher.

Additionally, the teacher of SMK Negeri 1 Lhokseumawe explained that one of the obstacles to implementing this supervision activity was the teacher's willingness and courage; initially, the teacher was hesitant and fearful of being supervised, as well as other obstacles, namely the existence of activities that required the teacher to perform other tasks, such as a visit to the school by the Deputy Superintendent. Additionally, the supervisor of the Lhokseumawe State Vocational School explained that if obstacles or delays prevented the school from carrying out scheduled supervision activities, the school would reschedule them after consulting with the supervisor and teacher to ensure that everything ran smoothly. This is consistent with Kristiawan's (2019) assertion that the success of education implementation in schools cannot be divorced from the supervisory, principal, and teacher roles. The teacher's primary responsibility is to instruct and assist pupils in resolving academic difficulties and advancing their personal and social development.

\section{CONCLUSION}

The objective of vocational high school institutions is to generate a generation capable of developing themselves in their chosen field of expertise through training and education. To accomplish this, vocational high schools must ensure that the proper learning process is followed according to specified standards. Continuous academic supervision has been scientifically demonstrated to boost teacher performance and professionalism. This research is limited to SMKN 3 and SMKN 1 Lhokseumawe. This study can serve as a model for other researchers interested in enhancing teacher effectiveness and professionalism in delivering academic supervision. This study's approach and findings can serve as a model for other schools.

\section{REFERENCES}

Aidil, Arnita. (2019). Supervisi Kepala Sekolah dalam Meningkatkan Manajemen Guru Bimbingan Konseling pada Sma Negeri 4 dan Sma Negeri 11 Banda Aceh. Tesis. Bnada Aceh. Pogram Pascasarjana Universitas Syiah Kuala.

Amanda, M. O., Salam, R., \& Saggaf, S. (2017). Pengaruh Supervisi Kepala Sekolah Terhadap Kinerja Guru di SMK Negeri 1 Bungoro Kabupaten Pangkep. In Prosiding Seminar Nasional Himpunan Sarjana Ilmu-Ilmu Sosial. 2 (1), 149-154. 
Astuti.S. (2016). Penerapan Supervisi Akademik untuk Meningkatkan Kompetensi Guru dalam Menyusun Administrasi Penilaian di SD Laboratorium UKSW. Scholaria :Jurnal Pendidikan dan Kebudayaan. 6 (1), 117-126

Astuti, S. (2017). Supervisi Akademik Untuk Meningkatkan Kompetensi Guru di SD Laboratorium UKSW. Scholaria: Jurnal Pendidikan dan Kebudayaan, 7(1), 49-59.

Bahri, S. (2014).Supervisi Akademik Dalam Peningkatan Profesionalisme Guru.Visipena Journal 5(1), 100-112.

Creswell. (2016). Research Design Pendekatan Kualitatif, Kuantitatif, dan Mixed Edisi Ket. Yokyakarta. Pustaka Belajar.

Creswell. (2017). Research Design Pendekatan Metode Kualitatif, Kuantitatif, dan Campuran Edisi Keempat. Yokyakarta. Pustaka Belajar.

Elliani, F. (2018). Pelaksanaan Supervisi Akademik Untuk Meningkatkan Kompetensi Guru Dalam Menyusun Rencana Pelaksanaan Pembelajaran (Studi Di Sd Negeri Lamklat Kecamatan Darussalam Kabupaten Aceh Besar). At-Ta'dib: Jurnal Ilmiah Pendidikan Agama Islam, $10(2), 174-181$.

Fitriani C, Murniati AR, N. Usman (2017). Kompetensi Profesional Guru dalam Pengelolaan Pembelajaran di MTS Muhammadiyah BandaAceh. Jurnal Administrasi Pendidikan Unsyiah, Volume 5, No. 2, Mei 2017.

Harahap, D. P. (2014).Supervisi Akademik Teknik Workshop Meningkatkan Kemampuan Guru Melaksanakan Pembelajaran Aktif. Jurnal Manajemen Pendidikan Indonesia, 6 (o2), 6776.

Ilham, Moch Wahid. (2017). Supervisi Pendidikan Dalam Perspektif Epistemologi Islam. Jurnal Pedagogik, Vol. 4 (1).

Kemat, (2016).Penerapan Supervisi Akademik Untuk Meningkatkan Kemampuan Guru Dalam Merencanakan dan Melaksanakan Pembelajaran.Manajer Pendidikan. 10 (6), 622-627.

Kristiawan, Muhammad., Yuyun Yuniarsih., Happy Fitria., Nola Refika.(2019). Supervisi Pendidikan. Bandung: Alfabeta.

Murniyati.,Messi., Wiwin Anggita Sari. (2018). Pelaksanaan Supervisi Akademik Pengawas Sekolah Sebagai Upaya Peningkatan Profesionalisme Guru. Jurnal Manajemen, Kepemimpinan, dan Supervisi Pendidikan. Volume 3, No. 1, Januari-Juni 2018.

Priansa, Donni Juni. (2014). Kinerja dan Profesionalisme Guru Fokus Pada Peningkatan Kualitas Pendidikan, Sekolah dan Pembelajaran. Bandung : Alfabeta.

Prasojo, Lantif, Sudiyono. (2015). Supervisi Pendidikan. Yokyakarta: Gaya Media.

Rachmawati, Tuti. (2016). Supervisi Pendidikan Sebagai Upaya Meningkatkan Kinerja Guru. Jounal Coopetition, Vol VII, Nomor 1, Maret 2016, 43 - 52.

Sujana, Nana et.al., (2017), Buku Kerja Pengawas Sekolah cetakan ke 7.Jakarta: Pusat Pengembangan Tenaga Kependidikan Kemdiknas.

Tanjung,Abdul Hamid.(2014). Pelaksanaan Supervisi Akademik dalam Meningkatkan Mutu Pembelajaran Pendidikan Agama Islam di Sd Negeri Lopian 2 Kecamatan Badiri Kabupaten Tapanuli Tengah. Tesis. Program Studi Pendidikan Islam Program Pascasarjana IAIN Sumatera Utara-Medan.

Wahyuni, U. (2015). Peran Guru Dalam Membentuk Karakter Siswa Di SDN Jigudan Triharjo Pandak Bantul Tahun Pelajaran 2014/2015. Jurnal UPI, 1:1-9

Warisno, Andi. (2018). Implementing A Quality Learning In Schools. Ar-Raniry, International Journal of Islamic Studies. Vol. 5 (1)

Zakso, A., \& Radiana, U. (2013).Pelaksanaan Supervisi Akademik Pengawas Sekolah Sebagai Upaya Peningkatan Profesionalisme Guru SMP Negeri 1 Bengkayang.Jurnal Pendidikan dan Pembelajaran, 2(3), 1-16. 